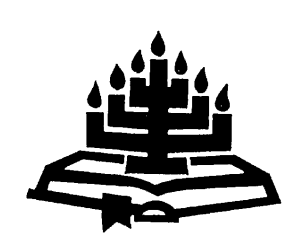

\title{
Ontwikkeling - die illusie van die twintigste eeu?
}

\author{
B.J. van der Walt \\ Skool vir Sosiale en Owerheidstudies \\ Potchefstroomkampus \\ Noordwes-Universiteit \\ POTCHEFSTROOM \\ E-pos: hannah@intekom.co.za
}

\begin{abstract}
Development - the illusion of the twentieth century?

Extensive research during especially the last decade has indicated inter alia that development has not been the success story so often portrayed; that the concept itself is not as clear as it was supposed to be and that the current kind of development is not necessarily the only way to advance human well-being. The question has even been asked whether development was not the great(est) illusion of the past fifty years. Christians and the various South African denominations which, because of the poverty in society, are getting involved in all kinds of development projects, should take cognisance of these scientific results about development. To prevent ultimate disappointment the aim of this article is not to reject the alleviation of poverty through development. An overview of the massive amount of available material intends to contribute towards more critical insight. By way of a brief historical overview this article first traces the origin and ideal of development. Without ignoring the successful projects, it then draws attention to the general failure of development. This is followed by a more detailed investigation into the possible reasons for its failure. In conclusion the alternative of a Christian perspective on development is considered.
\end{abstract}

\section{Opsomming}

Ontwikkeling - die illusie van die twintigste eeu?

Uitgebreide navorsing veral gedurende die afgelope dekade toon onder andere aan dat ontwikkeling glad nie die suksesverhaal was soos meestal voorgegee word nie; dat dit nie vanselfsprekend duidelik is wat presies met ontwikkeling 
beoog word nie en dat dit ook nie noodwendig die enigste wyse is waarop menslike welsyn nagestreef hoef te word nie. Om uiteindelik teleurstelling te voorkom, behoort Christene en kerke, wat as gevolg van die armoede in ons land by al meer ontwikkelingsprojekte betrokke raak, van sulke belangrike wetenskaplike bevindinge oor ontwikkelingswerk kennis te dra. Die doel van hierdie artikel is nie om armoedebestryding deur middel van ontwikkeling te verwerp nie. Deur middel van 'n oorsig oor die magdom stof oor die onderwerp wil dit 'n bydrae lewer tot 'n meer kritiese insig in die ontwikkelingsproblematiek. In 'n kort historiese oorsig gaan dit eers die oorsprong en ontwikkeling van die ontwikkelingsideaal na. Sonder om op die suksesvolle projekte in te gaan, vestig dit die aandag op die grootskaalse mislukking daarvan. Dit word opgevolg met 'n meer gedetailleerde ondersoek na die moontlike oorsake vir die mislukkings. Ten slotte word 'n moontlike alternatief vanuit 'n Christelike perspektief oorweeg.

\section{Inleidend: die groot droom van 'n beter samelewing}

Mense van alle tye - insluitende onsself in die nuwe Suid-Afrika - is geboei en word graag meegevoer deur 'n visie op 'n beter, ideale samelewing waarin almal die goeie dinge van die lewe sal kan geniet. Een manier waarop so 'n samelewing gedurende die afgelope vyftig jaar met groot ywer oor die hele wêreld nagestreef is, was deur middel van die towerwoord "ontwikkeling". Selfs vandag nog word feitlik enigiets wat onder die vlag van "ontwikkeling" aangepak word, byna kritiekloos, met oop arms vanselfsprekend as iets goeds aanvaar. Vrae soos wat ontwikkeling is, waarom dit moet plaasvind en watter gevolge dit inhou, word dikwels nie eers gestel nie - ten minste nie in die praktyk van ontwikkelingswerk nie.

Nie net regerings en nie-regeringsorganisasies (sg. NGO's) is by ontwikkelingswerk betrokke nie. As gevolg van skreiende armoede raak al meer kerke in Suid-Afrika betrokke. Dit sluit die gereformeerde kerke in (vgl. bv. Dyers, 2001 en Schoeman, 2000). Kritiese besinning oor ontwikkeling is dus nie 'n akademiese luukse nie, maar 'n praktiese noodsaaklikheid. Hierdie artikel wil in die noodsaaklike behoefte daaraan voorsien. Sonder om negatief te wees, wil dit die aandag daarop vestig dat (vgl. byvoorbeeld Buijs, 2001; Rist, 1999 en Schuurman, 1993) die hele ontwikkelingsideaal tans in 'n impasse beland het en na 50 jaar die "krisis van die middeljare" beleef.

Die artikel is oorsigtelik van aard, maar met die bedoeling om tot beter insig te lei. In die eerste plek word 'n kort historiese oorsig 
gegee met die bedoeling om vas te stel wat presies met die begrip "ontwikkeling" bedoel word. Daarna word die aandag gevra vir die grootskaalse mislukking daarvan. Vervolgens word die moontlike redes vir die mislukkings in groter detail ondersoek. Ten slotte word besin oor die moontlikheid of ontwikkelingswerk vanuit 'n Christelike perspektief in 'n gesonder rigting gestuur kan word.

\section{2. 'n Kort historiese oorsig oor die ideaal van ontwikkeling}

Die volgende paar flitse uit die geskiedenis wil help om 'n beter insig te gee van wat met die konsep "ontwikkeling" bedoel word. (Nuttige bronne in dié verband is Rist, 1999 en Sachs, 1992 en 1999.)

\section{Die vyftigerjare}

Die ontwikkelingsideaal van die Weste vir die res van die wêreld begin op 20 Januarie 1949 met die inougurele rede van die Amerikaanse president, Truman. Die hoofgedagte daarvan is dat die Weste in die plek van die ou kolonialisme op 'n nuwe manier by die armer nie-Westerse lande betrokke moet wees, naamlik ontwikkeling deur middel van Westerse wetenskap, tegnieke en ekonomie.

Omdat dit so 'n sleutelteks is, haal ek uit Truman se "Point four message" (vgl. Rist, 1999:249-250 vir die volledige teks) net drie paragrawe aan.

Fourth, we must embark on a bold new program for making the benefits of our scientific advances and industrial progress available for the improvement and growth of underdeveloped areas.

Met hierdie paar woorde is die hele wêreld op 20 Januarie 1949 in twee groepe verdeel: die "ontwikkelde" Weste en die "onderontwikkelde" res van die wêreld. Omdat die Weste ekonomiestegnies verder gevorder het, sou dit ook meer ontwikkeld wees. Vanaf die begin van die geskiedenis van die ontwikkelingsideaal is die begrip dus baie eensydig of reduksionisties verstaan en dié eng visie op ontwikkeling (as iets tegnies-wetenskaplik-ekonomies) is nooit heeltemal prysgegee nie. Ook nie die gedagte dat die Weste dié model is vir elke vorm van ontwikkeling elders in die wêreld nie.

Truman vervolg: 
Greater production is the key to prosperity and peace. And the key to greater production is a wider and more rigorous application of modern scientific and technical knowledge.

Tereg merk Van Aalsburg (2002:11 e.v.) en Vreugdenhil (2003:13, 22) op dat die Weste se geloof in die wetenskap (scientisme) en tegnologie (tegnisisme) hier duidelik blyk. Ook die eensydige ekonomiese aksent is baie duidelik: ontwikkeling is ekonomiese ontwikkeling en onderontwikkeling beteken om nie materieel ryk te wees nie.

\section{'n Laaste aanhaling uit Truman:}

The old imperialism - exploitation for foreign profit - has no place in our plans. What we envisage is a program of development based on the concepts of fair-dealing.

Van hierdie mooi voorneme het volgens die meeste skrywers weinig tereg gekom. In plaas van internasionale altruïsme, getuig die verdere verloop van die ontwikkelingsideaal eerder van 'n nuwe vorm van Westerse paternalisme. Deur middel van "ontwikkeling" het die Weste probeer om sy houvas op sy vroeëre kolonies te behou.

Vreugdenhil (2003:14) toon byvoorbeeld aan dat Nederland ontwikkelingshulp gegee het omdat dit in Nederland se eie belang was; dit Nederland se internasionale aansien sou bevorder; dit hom sou help om deur 'n agterdeur weer toegang tot sy ou kolonies (bv. Indonesië) te verkry; dit werk sou verskaf aan Nederlandse amptenare wat as gevolg van dekolonisasie hulle werk sou verloor.

Meer in die algemeen gee Van Aalsburg (2002:31) die volgende drie redes waarom die Weste vir die ontwikkelingsmotief gekies het bo ander vorme van intervensie:

- Dit was vir (sowel die Weste as hulle vroeëre kolonies) meer aanvaarbaar as die vroeëre meer openlike imperialistiese kolonialisme.

- Die nie-Westerse lande was, volgens die Westerse geloof in modernisering en vooruitgang (deur middel van wetenskap, tegnologie en ekonomie), nog onder aan die leer van ontwikkeling.

- Om in plaas van vir ontwikkeling liewer vir armoedebestryding te kies, sou pynlike selfkritiek by die Weste noodsaak, omdat kolonisasie tot die armoede van die nie-Westerse lande bygedra het. 
Die sestigerjare was 'n tyd van groot optimisme oor die moontlikhede van ontwikkeling. In 1961 verklaar die Verenigde Nasies dié periode as die eerste ontwikkelingsdekade. Al is dit op paternalistiese wyse, wou die Weste deur middel van finansiële ontwikkelingshulp sy welvaart deel met die armer wêrelddele.

Die sewentigerjare is egter al minder optimisties, omdat dit duidelik begin word dat Westerse geld, kennis (wetenskap) en tegniek nie die verwagte resultate oplewer nie. Van nou af word gereeld geëksperimenteer met nuwe modelle vir ontwikkeling. In plaas van Westerse paternalisme, word byvoorbeeld meer klem op lokale deelname geplaas.

Die tagtigerjare is tot nog 'n mindere mate optimisties. Ontwikkelende lande is nie in staat om hulle skulde vir ontwikkelingshulp aan die Westerse banke terug te betaal nie. Allerlei strukturele aanpassingsprogramme word dus in werking gestel, wat op hulle beurt weer groot armoede en ander ellendes in die ontwikkelende lande veroorsaak.

Die negentigerjare bring nog groter onsekerheid en nog meer nuwe aksente om ontwikkeling tog op dreef te hou: meer klem op lokale omstandighede, deskundigheid en deelname, beter plaaslike regerings, groter stryd teen armoede en voorsiening van basiese behoeftes. Die blote oordrag van Westerse geld, kennis en tegnologie het duidelik nie geslaag nie.

Die eeuwisseling bring ons by wat die "middeljarige" krisis van die ontwikkelingsideaal genoem word. Aan die een kant word tans nog meer nuwe aksente gelê, byvoorbeeld op 'n meer geïntegreerde aanpak, klem op volhoubare (sustainable) ontwikkeling, groter effektiwiteit en dus die noodsaak om die geslaagdheid van projekte te kan meet. Aan die ander kant gaan daar steeds meer kritiese stemme op dat die ontwikkelingsideaal as sodanig bevraagteken moet word. Die kritiek raak die volgende (vir besonderhede vgl. Vreugdenhil, 2003:17-22): die motiewe agter die ontwikkelingsideaal, die metodes, die resultate, maar ook die ontwikkelingsbegrip self.

Wat die konsep "ontwikkeling" betref, toon Vreugdenhil (2003:22, vgl. ook Van Aalsburg, 2002: 11, 23) aan dat veral twee trekke dit dwarsdeur die afgelope vyftig jaar kenmerk: die sterk reduksionistiese beklemtoning (alle klem slegs op die ekonomiestegniese) en die sterk Eurosentriese trek daarvan (die res van die wêreld kan alleen volgens die Westerse model "ontwikkeld" word). 


\section{Die groot mislukking}

Die talle geskrifte oor ontwikkeling lê (veral aan die begin) graag klem op die gebrekkige toepassing van die ontwikkelingsteorieë in die praktyk as die oorsaak vir die mislukking van die ontwikkelingsideaal. Dit is egter ook ' $n$ feit dat die ontwikkelingsmodelle voortdurend aangepas is namate geblyk het dat hulle nie die verwagte praktiese resultate opgelewer het nie. Die basiese geloof in onbeperkte groei en vooruitgang is dus wel verander, dog nooit heeltemal verwerp nie. Ten spyte daarvan het die werklike resultate nie gerealiseer nie.

Voordat op die mislukkings ingegaan word, moet egter eers uitdruklik gestel word dat hierdie artikel nie wil ontken dat daar ook geslaagde ontwikkelingsprojekte was nie. Harrison (1987) analiseer byvoorbeeld dertien projekte wat destyds in Afrika suksesvol was. Vreugdenhil (2003:20) se konklusie is egter dat die meeste ontwikkelingsprojekte maar 'n klein klompie mense net vir 'n klein rukkie 'n klein bietjie kon help. Schneider (1988) toon byvoorbeeld aan waarom, van die ongeveer veertig reuse projekte (damme en hidro-elektriese kragsentrales) wat dwarsoor die wêreld opgerig is om ontwikkeling te bevorder, 39 uiteindelik klinkklare mislukkings was toe die implikasies daarvan vir die mense en omgewing duidelik geword het (vgl. Van der Walt, 1999:198-199 vir detail).

Ek gee eers enkele uitsprake wat daarop dui dat eerder onderontwikkeling as ontwikkeling die gevolg was van die baie projekte in die sogenaamde Derde Wêreld. Vervolgens word daarop gewys dat ontwikkeling die heel grootste probleem van die wêreld, naamlik armoede, nie kon oplos nie. Daarna volg meer spesifieke nadelige gevolge.

\subsection{Onderontwikkeling nie die begin nie - dog die eindpunt}

Reeds in 1972 skryf Rodney (herdruk 1989) 'n boek How Europe underdeveloped Africa. Ander denkers (wat nie sy Marxistiese oortuigings gedeel het nie) laat egter dieselfde waarskuwing hoor. So byvoorbeeld Zeylstra (1975:253):

... every country has precisely the level of productivity that it ought to be expected to have in view of its cultural-historical circumstances ... it's rather the modernization process which is the basis of the creation of underdevelopment.

Ook volgens Verhelst (1990:61) is die onderontwikkeldheid van die sogenaamde Derde Wêreld nie die begin nie, maar die eindresultaat 
van die Weste se "ontwikkelingsprogramme". Talle ander skrywers (vgl. byvoorbeeld Escobar, 1995) beweer dat die integrasie van die armer lande in die ekonomie van die ryk Weste - 'n proses wat deur globalisering steeds versnel word - hulle eerder onderontwikkeld as ontwikkelend gemaak het en nog steeds maak.

Dit beteken nie dat die Westerse lande beter daaraan toe is nie. Terwyl die nie-Westerse, suidelike lande siek is as gevolg van onderontwikkeling, ly die noordelike lande aan 'n ander siekte, dié van (ekonomiese) oorontwikkeling. Verhelst (1990:69) beskryf dié siekte soos volg:

A society that reduces everything to profit, acquisition and power is a sick society: sick in the very definition of its values, sick to the depths of its cultural being. The West has become culturally underdeveloped because it, too, is the victim of the idea of progress and the model of development which it has transmitted to the Third World and which is imposed on itself ... It is an alienation amidst plenty and at least as dehumanizing as alienation in poverty.

In die volgende uitspraak (Verhelst, 1990:70) gee hy sommige van die belangrikste redes vir die Westerse malaise:

Today the West is under the threat of its own pan-economic model, which reduces everything to its market value. Such a reduction, combined with an obsession with productivity, consumerism and competitiveness, sow unhappiness and confusion. Paradoxically, this occurs while the quest for happiness, greatly aided by advertising, is increasingly advocated ... it is striking that the West can talk of nothing else ... This desire is like a gaping void ... the West has tried to fill this void ... clutching to objects ... having plenty ... Western modernity is in search of a 'false infinite', that is to say a quantitative in-finite according to which one constantly produces, consumes and 'progresses'.

(Vgl. Van der Walt se artikel oor globalisering in hierdie selfde nommer van In die Skriflig wat hierdie uitspraak verder ondersoek en staaf.)

\subsection{Mislukte stryd teen armoede}

Die verwagting dat ontwikkeling veral die suide se ernstige armoedeprobleem sou oplos, was ook 'n illusie. Na vyftig jaar se ontwikkelingswerk (so konkludeer Buijs, 2001:255) het die persentasie armoede wel afgeneem, maar tegelykertyd is die aantal armes 
groter as ooit en moet gekonstateer word dat ook die kloof tussen armes en rykes nog steeds groei: die baie armes word armer en die enkele rykes ryker. Buijs (2001:208) het dus kritiek op die Wêreldbank se World Development Report 2000/2001; attacking poverty (Worldbank, 2000), wat slegs die afname in die persentasie armes noem en só die feit versluier dat die aantal armes nog steeds groei. In sekere lande was daar wel sprake van ontwikkeling, maar dit was nie ewewigtig nie. Die welstand van die middelklas het verbeter, maar die gaping tussen ryk en arm in dieselfde land het vergroot (vgl. Buijs, 2001:147).

Dit het uiteindelik begin duidelik word dat armoede nie iets is wat bloot met meer geld en tegnologie bestry kan word nie. Armoede is 'n komplekse vraagstuk, baie dieper en harder as iets bloot ekonomies-sosiaals (vgl. Buijs, 2001:230, 258 e.v.). Armoede verontmenslik die mens. Om dit op te los vereis dus nie noodwendig meer kapitaal nie, maar regverdigheid in toegang tot en seggenskap oor bronne, beter opleiding, meer geleenthede en ander vorme van bemagtiging.

Ontwikkeling het egter nie net die armer lande armer gemaak nie. Ook vroeër ryk, Westerse lande word armer. Nie noodwendig die lande as sodanig nie, maar die arm individue in die lande word meer teenoor 'n klein groepie ryk elite.

\subsection{Nog meer simptome van mislukking}

Sonder om op die detail in te gaan (vgl. Fowler, 1998:407 e.v. en 2002:75-80) word die volgende nadelige gevolge van ontwikkeling net genoem. Hierdie gevolge is reeds baie duidelik in Westerse lande, dog in toenemende mate ook in die nie-Westerse wêreld. Sommige van die belangrikste gevolge is die volgende: negatiewe gevolge vir gesondheid; toenemende geestelike versteurings; groeiende geweld; dwelmverslawing; 'n krisis in alle versorgingsberoepe; werkloosheid en die vernietiging van die natuurlike omgewing.

Goudzwaard en De Lange (1994) vat die gevolge van ontwikkeling goed saam deur nie net van voor- en nadele te praat nie, maar van sekere paradoksale verskynsels in sowel die ryk as die arm lande. Hulle noem die volgende ses paradokse, waarvan ons die een pool van sommige reeds hierbo teëgekom het:

- die paradoks van skaarste: ongekende oorvloed met groter skaarste as ooit tevore; 
- die gesondheidsparadoks: verbeterde mediese sorg, maar terselfdertyd ' $n$ toename in allerhande moderne liggaamlike en geestelike siektes;

- die tydsparadoks: steeds meer werk- en tydbesparende apparate, terwyl ons almal minder tyd het;

- die paradoks van armoede: toenemende oorvloed en weelde (in 'n kwart van die wêreld) tesame met skreiende armoede (in 'n driekwart van die wêreld);

- die arbeidsparadoks: groter behoefte by meer mense aan werk, maar terselfdertyd steeds groeiende werkloosheid, en

- die versorgingsparadoks: groter moontlikhede vir die beter versorging van mens en natuur tesame met afnemende, gebrekkiger sorg aan die medemens en die omgewing.

Indien so 'n grootse projek, wat nagenoeg 'n halwe eeu geduur het, waaraan miljarde der miljarde bestee is en waaraan miljarde mense deelgeneem het, in die meeste gevalle op 'n fiasko uitgeloop het, moet die moontlike redes daarvoor met groot erns ondersoek word.

\section{Moontlike oorsake vir die mislukking van die ontwikkelingsideaal}

Die talle nadelige gevolge van vyf dekades van "ontwikkeling" dien as rooi waarskuwingsligte wat nie sonder verdere skade geïgnoreer mag word nie.

In sommige van die huidige debatte gaan dit selfs nie meer net daaroor om met behoud van die ontwikkelingsideaal die nadelige gevolge te probeer vermy of verminder nie. Ontwikkeling self verkeer in diep onsekerheid. Baie ontwikkelingsaktiwiteite word steeds onderneem, maar die regverdiging daarvoor ontbreek (vgl. Buijs, 2001:33). Ontwikkeling beleef die krisis van sy "oorgangsjare". Vrae soos die volgende word al meer gestel: Moet ons nie die heilige koei van onbeperkte ekonomiese groei verbrand, die feëverhaal van die mark verwerp en die fiksie van die geluk van oorvloed vir almal ontmasker nie? Indien ons voor 1950 sonder "ontwikkeling" kon klaarkom, waarom nie ook vandag, nie? Moet ons nie erken nie dat ontwikkeling 'n dooie ster was waarvan daar wel 'n lig uitgegaan het, terwyl die ster self lank gelede al gesterf het?

Omdat die oorsake (wat soms moeilik van die gevolge onderskei kan word) so belangrik is vir die verstaan van die probleem, word hulle in meer detail behandel. Dit word gedoen sonder om 
naastenby na volledigheid te streef. So byvoorbeeld word nie eers aandag gegee nie aan die feit dat, as gevolg van politieke en ander druk, die ontwikkelingsproses (wat in Europa eeue geduur het) in nie-Westerse lande oorhaastig moes plaasvind.

\subsection{Onduidelike en verkeerde motiewe}

Verskillende bronne vestig die aandag daarop dat nie net humanitêre motiewe (soos byvoorbeeld simpatie, bewoënheid oor armes, sosiale geregtigheid en dies meer) 'n rol by ontwikkeling gespeel het nie. Die volgende word genoem (waarvan sommige reeds aangestip is):

- Ontwikkelingshulp het die Westerse lande beter laat voel oor hulle eie rykdom en die noodsaaklikheid om te vra waar hulle dit vandaan gekry het (deur koloniale uitbuiting), verdoesel.

- Ontwikkeling spruit uit 'n skuldige gewete oor eeue van slawerny, koloniale en post-koloniale uitbuiting.

- Ontwikkeling was 'n (nie-politieke) strategie om die wêreldorde ná dekolonisering tot voordeel van die Weste te stabiliseer.

- Ontwikkelings(hulp) is gedurende die Koue Oorlog (1948-1988) gebruik om die lojaliteit van die onderontwikkelde wêreld vir óf die Westerse óf die Kommunistiese blok te koop. Die VSA het dekolonisering en ontwikkeling daarna bloot gesteun om die koloniale markte vir homself te bekom.

- Ontwikkeling is dus nooit as gevolg van altruïstiese oorwegings oor die welsyn van die armer lande gedoen nie, maar spruit voort uit die eiebelang van die ryker lande.

Hoe belangrik motiewe werklik is, blyk onder andere uit Hoofstuk 10 van Buijs (2001:191 e.v.). In die motiewe lê die beginpunte, die norme vir ontwikkeling. Veral sedert die negentigerjare gaan dit in ontwikkeling egter hoofsaaklik oor die eindpunt, naamlik die feitelike resultate, die effektiwiteit of die impak, wat volgens 'n bedryfsmatige aanpak geouditeer en gekwantifiseer moet word. Só word ontwikkeling sinloos, 'n leë dop. Duidelike en suiwer motiewe is belangrik.

\subsection{Ontwikkeling as kultuuroordrag, -verandering en -vernietiging}

Dit het geleidelik duidelik begin word dat ontwikkeling en kultuur nie twee afsonderlike sake is nie, maar dat ontwikkeling self ' $n$ kulturele 
produk is. (Kyk die studies van Van der Walt, 1999, 2001 en 2003 wat op hierdie aspek toespits.) Nie alleen die kultuur van die "ontvangers" van ontwikkeling is belangrik nie, maar ook die Westerse "gewers" van ontwikkeling, binne wie se kultuur die idee van ontwikkeling ontstaan het. Soos elke kultuur, het dit 'n religieuse kern. Die sekulêre Westerse religie bepaal die Westerse visie op die ideale samelewing wat deur ontwikkeling vir die hele wêreld gerealiseer moes word.

In sy onlangse werk sê Leistner (2003) byvoorbeeld dat die belangrikste rede vir Afrika se ontwikkelingsprobleme nie die nodige aandag ontvang nie. Dit is 'n feit dat Afrikane se kultuur en lewensvisie fundamenteel van dié van die Weste verskil en konflik tussen die twee se idees oor ontwikkeling dus onvermydelik is. Afrikane se basiese dilemma is dat hulle aan die een kant graag (ekonomies) wil ontwikkel, maar aan die ander kant vrees dat hulle 'n te duur prys daarvoor sal moet betaal, naamlik dat hulle gedwing sal word om hulle lewensvisie en tradisionele waardes - niks minder as hulself nie - prys te gee. So 'n vrees behoort volgens Leistner met simpatie bejeen te word.

Kort saamgevat, is die probleme in dié verband die volgende:

- Die Westerse kulturele ideale, soos in ontwikkeling vervat, het in baie opsigte nie net totaal verskil van die nie-Westerse kulture nie, maar selfs daarmee gebots. (Vergelyk byvoorbeeld Van der Walt, 1999 en 2003 vir die radikale verskille tussen die Westerse en Afrikakultuur.) Die gevolg was die weerstand teen en mislukking van ontwikkelingspogings.

- Die Weste het vasgehou aan die geloof in die meerderwaardigheid van sy eie kultuur (as "ontwikkeld" teenoor "onderontwikkeld").

- Saam daarmee is geglo dat die Westerse kultuur universele geldigheid besit, sodat dit na ander wêrelddele oorgeplaas kon word en húlle "probleem" (van "onderontwikkeld" te wees) eensklaps daarmee opgelos sou wees.

- Verder was daar min of (aanvanklik) geen besef van die ingrypende gevolge van Westerse kultuuroordrag en kultuurintervensie nie, soos byvoorbeeld dat dit inheemse kulture vernietig het en tot identiteitsverlies, verlies aan selfrespek en afhanklikheid sou lei nie - omstandighede waaronder ontwikkeling nie werklik kon plaasvind nie. Rist (1999:79) merk tereg 
op dat deur ontwikkeling twee miljard mense nie net hulle "selfdetermination" maar ook hulle "selfdefinition" verloor het.

'n Uitstekende boek uit die pen van 'n Afrikaan self oor hierdie problematiek met ' $n$ veel meer gebalanseerde oplossing daarvoor is Gyekye se Tradition and modernity; philosophical reflections on the African experience (1997). Veral Hoofstuk 8 (Gyekye, 1997:217 e.v.) en die epiloog (Gyekye, 1997:273 e.v.) is noodsaaklike leesstof vir enigeen wat insig wil verkry in die wyse waarop die tradisionele Afrikakultuur en modernisering (ontwikkeling) gekombineer behoort te word.

\subsection{Ontwikkeling as iets eensydig ekonomies en tegnies}

Ten spyte van die feit dat verskillende opeenvolgende ontwikkelingsparadigmas geleidelik meer "menslike" elemente bygevoeg het, het ekonomiese ontwikkeling die vertrekpunt en norm gebly. So 'n standpunt heet ekonomisme, 'n oorbeklemtoning, oordrywing en verafgoding van een aspek van die ryke verskeidenheid van die mens en die werklikheid. Die ekonomiese word dan, in plaas daarvan dat dit normatief beoordeel word, die doel, middel en norm vir ware, volle lewe. Alles word ekonomies bekyk en beoordeel. In so 'n beskouing is die sterkste skelwoord "onekonomies". Dit lei tot 'n uiters beperkte visie op die werklikheid en verblind die mens vir die waarde van ander, ewe belangrike aspekte van sy bestaan. Menslike welsyn, volledige menswees, word tot welvaart gereduseer. Nie-ekonomiese dinge het óf eenvoudig nie waarde nie óf hulle word - teen hulle eie aard in - verkommersialiseer.

Welvaart kan as middel 'n belangrike bydrae tot breë menslike welsyn maak. Wanneer van welvaart egter 'n doel op sigself gemaak word, kan dit menslike welsyn in die wiele ry. Daarom behoort dit altyd in diens te staan van breër kulturele ontwikkeling en ontplooiing.

Volgens Neef (1995) lei ontwikkelingsekonome aan "collective madness", omdat hulle glo dat ekonomiese groei en vooruitgang net goed en nie ook ongesond kan wees nie. Syns insiens behoort daar onderskeid gemaak te word tussen groei en ontwikkeling. Alle lewende stelsels groei tot op 'n bepaalde punt en hou dan op groei, wat nie beteken dat hulle ophou om te ontwikkel nie. Sy "thresholdhypothesis" kom daarop neer dat ekonomiese groei net tot op 'n sekere punt 'n mens of gemeenskap se lewenskwaliteit kan verbeter. Ná dié punt kan die groei wel voortgaan, maar die lewenskwaliteit verbeter nie, maar gaan eerder agteruit. Die ekonomies oorontwikkelde Weste is, soos hierbo reeds geblyk het, 
'n duidelike voorbeeld daarvan. Neef se hipotese word in die praktyk bevestig as Rist (vgl. 1999:206) daarop wys dat vasgestel is dat hoë vlakke van menslike ontwikkeling met 'n beskeie inkomste moontlik is, terwyl swak menslike ontwikkeling in die geval van hoë inkomstes voorkom. Tereg merk hy elders op: "Wealth is evidently not the good we are seeking, for it is merely useful for the sake of something else" (Rist, 1999:9).

\subsection{Ontwikkeling volgens verkeerde ekonomiese paradigmas}

Hierdie aspek hang nou met die vorige saam. Die verskil is dat die klem hier op die (ekonomiese) teorieë self val waarvolgens ontwikkeling moes plaasvind en die definisies wat hulle van ontwikkeling gegee het. In dié verband kan daar moeilik 'n beter bron as die indringende studie van Rist (1999) gevind word. (Ander insiggewende werke is dié van Harrison, 1988 en Hettne, 1995.)

Rist se boek behandel al die sleuteltekste wat die afgelope halfeeu 'n belangrike rol in die geskiedenis van die ontwikkelingsideaal gespeel het. Al die "definisies" wat in hierdie tekste gegee word, is variasies op dieselfde tema en is buitendien vol interne kontradiksies. Volgens Rist is die begrip "ontwikkeling" geleidelik gedreineer van enige betekenis, sodat dit tans nog bloot 'n "oorblyfsel" is ter regverdiging van die proses van globalisering (vgl. Van der Walt se artikel oor globalisering in hierdie nommer van In die Skriflig). Ontwikkeling - wat dit ook mag inhou - is nie meer die vertrekpunt nie, maar sal bloot die eindresultaat van globalisering wees (vgl. Rist, 1999:6).

Die krag van die ontwikkelingsidee lê dus nie in die teoretiese duidelikheid of motiveringskrag van die ekonomiese definisies daarvan nie. Ontwikkeling ontleen volgens Rist eerder sy krag aan die feit dat die idee mense fassineer.

Volgens hom is die hele ontwikkelingsgedagte gegrond op ekonome se verkeerde gelykstelling tussen biologiese groei en die ontwikkeling van die menslike geskiedenis en samelewing. Soos wat 'n organisme groei, net so moes ook die samelewing ontwikkel. Daarom word (ekonomiese) ontwikkeling gesien as iets vanselfsprekend, noodsaaklik en positief, wat dus nie bevraagteken mag word nie. Verder is ekonomiese ontwikkeling iets onomkeerbaar en permanent, wat onbeperk kan voortduur en hoe meer groei kan plaasvind, hoe beter. Ten slotte kon hierdie vooruitgangsgeloof - 'n versekularisering van die Christelike toekomsverwagting - nie bestaan sonder die idee van onderontwikkeling waaraan dit negatief 
gebonde is nie. Rist (vgl. 1999:168) huiwer nie om te sê nie dat so 'n naturalisties-biologistiese visie op die mens die samelewing tot 'n "menslike dieretuin" reduseer.

Sy konklusie (Rist, 1999:236) is eenvoudig dat ontwikkeling nooit kan slaag nie, omdat groei en vooruitgang nie onbepaald en onbeperk kan voortduur nie. Dit is 'n geloof wat die moderne Westerse kultuur van alle ander kulture onderskei. Verder deel ontwikkeling ook die geloof dat meer produksie en verbruik noodwendig ook beter is as die soberheid en beperking van begeertes. Sy oplossing vir die probleem is dan ook dat die onderliggende idees by die ontwikkelingsekonomieë tot op die wortel oopgevlek moet word.

\subsection{Voordurende aanpassings - sonder om die konsep self te bevraagteken}

'n Paradigma sterf moeilik. Dit word eerder verander en aangepas by die harde feite wat dit weerspreek, of nuwe ad hoc-hipoteses word ontwerp - veral om die belange van magtiges te beskerm. Dit het ook in die geval van die ontwikkelingsteorieë gebeur: die basiese geloof in onbeperkte groei, wat 'n paradys van welvaart sou bring, mog nie prysgegee word nie, maar is voortdurend aangepas. Vandaar die groot aantal ontwikkelingsteorieë die afgelope vyftig jaar. Enkele van hierdie teorieë was die volgende: ekonomiese hulp; ekonomiese groei; die bevrediging van basiese behoeftes; landelike ontwikkeling; die ontwikkeling van vroue; die teëwerk van bevolkingsaanwas; die verligting van armoede; die ontwikkeling van menslike hulpbronne; werkskepping; die herverdeling van grond en rykdom, en volhoubare ontwikkeling.

'n Mens sou veronderstel dat die nuutste tendens in die ontwikkelingsdenke, naamlik "volhoubare ontwikkeling", 'n nuwe geluid laat hoor het. Is dit nie so dat feitlik geen projek vandag aanvaar word as dit nie as sustainable beskou kan word nie?

Rist (1999:179-196) toon egter met 'n noukeurige analise en vlymskerp kritiek op die oorspronklike dokumente (waaraan die konsep "volhoubare ontwikkeling" sy oorsprong te danke het) aan dat ook "volhoubare ontwikkeling", dié huidige slagspreuk, hoegenaamd nie 'n duidelike begrip is nie. Hierdie slagspreuk het sy sukses eerder aan sy onduidelikheid en dubbelsinnigheid te danke. In plaas van om die spanning tussen onbeperkte ekonomiese groei en ekologiese grense op te los, het dit 'n keuse tussen die twee probeer vermy. Die sleuteldokumente is uiters vaag en omskryf nóg 
"ontwikkeling" nóg "volhoubaarheid" duidelik. Eintlik word die rolle omgekeer: Dit is nie die oorlewing van die ekosisteem wat grense aan ontwikkeling stel nie maar, omgekeerd, ontwikkeling wat die oorlewing van die omgewing en die samelewing moet verseker. Op die keper beskou, is "ontwikkeling" die belangrikste element en die toegevoegde kwalifisering, "volhoubaar", bied slegs 'n nuwe legitimasie daarvoor. Dit is egter onbegryplik hoe 'n voortgesette groeibeleid die natuurlike omgewing sou kon beskerm. Soos die begrip self sê (al verstaan ekoloë dit anders) beteken "sustainable development" dat ontwikkeling self voortgesit moet word - die klem lê eerder op ontwikkeling as op volhoubare! Rist is nie verkeerd as hy konkludeer dat die probleem (van onbeperkte ontwikkeling) as oplossing aangebied word nie.

Omdat Rist dalk as te radikaal en selfs sinies bestempel kan word, kan verwys word na iemand uit 'n heel ander milieu ('n Moslemdenker). Ook Sardar (1996:43) beskou die kombinasie van "volhoubaar" en "ontwikkeling" as 'n teenstrydigheid in sigself. Voortgaande ontwikkeling volgens die Westerse model kan volgens hom nie terselfdertyd ook volhoubaar wees nie. Hy sê dat nie-Westerse lande al eeue lank volhoubaar en ekologies bewus was en dus nie lessies in volhoubare ontwikkeling van die Weste, "one of the most unsustainable of all civilizations", nodig het nie.

\subsection{Ontwikkeling self die norm}

Een van die belangrikste redes volgens Van der Walt (1999:234242) vir die mislukking van Westerse ontwikkelingspogings is dat 'n duidelike normatiewe besef daarin ontbreek. Hierdie afwesigheid van norme hou verband met die neutraliteitsgedagte wat vir eeue tot nog onlangs die Westerse wetenskapsbeoefening - insluitend die ontwikkelingswetenskappe - beheers het. Volgens hierdie positivistiese wetenskapsideaal moes wetenskap bloot deskriptief die feite beskryf en mog dit nie preskriptief norme toepas nie. Gevolglik is norme of waardes nie duidelik gestel nie, maar meestal veronderstel, want geen mens kan werklik neutraal of normloos dink nie. Die rede waarom die norme nie so duidelik raakgesien is nie en meestal verskuil is, lê in dié tipe wetenskapsbeoefening se visie op norme. Norme is nie werklik as norme erken nie, maar met feite of dinge verwar. Die aard van werklike norme is dat hulle geld, grense aandui, rigting en koers verskaf. Dinge moes nou dié rol van ware norme vervul.

In die Reformatoriese tradisie word so 'n visie op norme en wette as "subjektivisme" aangedui, omdat subjékte (dit wil sê dinge wat aan 
wette onderworpe en gehoorsaam moet wees) oorskat word en die plek van norme inneem. Op dié wyse verloor goddelike verordeninge en daarvan afgeleide menslike norme hulle unieke aard: Hulle word nie meer skerp onderskei van dit waarvoor hulle geld nie; kan nie helder onderskei tussen reg en verkeerd, goed en sleg nie; stel nie meer grense tussen wat mag en nie mag of behoort nie; dui nie meer duidelik rigting aan nie; hoef nie werklik gehoorsaam te word nie - wat kan, mag ook.

Eenvoudig gestel, beteken subjektivisme dat wat is ook behoort te wees. Gevolglik is dinge soos ontwikkeling, die vrye mark, kompetisie, vooruitgang, produksie, verbruik, ensovoorts, as sodanig goed, in plaas daarvan dat hulle normatief beoordeel moet word om te kan bepaal of hulle goed of sleg is.

Die nadelige gevolge van hierdie subjektivisme is vandag duidelik by sowel ontwikkeling as globalisering (kyk Van der Walt se artikel in hierdie nommer van In die Skriflig):

- Omdat normatiewe grense verval het, geld die wet van die oerwoud (die oorlewing van die sterkste) in 'n meedoënlose kompetisie tussen mense en mag ook die natuur roekeloos vernietig word.

- Omdat normloosheid tot koersloosheid lei, heers onsekerheid en vaagheid (sien Rist hierbo) oor wat ontwikkeling en globalisering presies inhou en volg die een model of hipotese op die ander. Die een na die ander saak word tot norm verabsoluteer, byvoorbeeld eers industrialisasie, dan ontwikkelingshulp, vervolgens basiese behoeftes, daarna volhoubaarheid en tans globalisering.

- Subjektivisme lei ook tot relativisme. As die dinge ("isse") self die wette word (van wat behoort), dan is 'n mens verplig om die bestaande as reg en goed te aanvaar, dan mag 'n mens nie meer krities onderskei en beoordeel tussen goed en kwaad, reg en verkeerd nie. Alles kom op losse skroewe te staan, vastigheid en sekerheid bestaan nie meer nie. (Vergelyk byvoorbeeld die onduidelikheid oor volhoubare ontwikkeling, hierbo beskrywe.)

- As ontwikkeling die norm geword het, hoef dit nie geregverdig te word en kan dit ook nie bevraagteken word nie - dit regverdig sigself. Dit word 'n geslote sirkel: ontwikkeling ter wille van ontwikkeling.

- Sonder werklike norme verval ontwikkeling ook in pragmatisme en utilisme: die doel of resultaat word die norm. Ook die middele ter bereiking van die doel hoef nie normatief getoets te word nie. 
- Die resultaat van ontwikkelingswerk moet deesdae ook kwantifiseerbaar wees. Getalle (met ander woorde dinge) word tot die belangrikste en enigste norm verhef. Wat nie getel kan word nie - hoe meer hoe beter - tel eenvoudig nie.

- Geen wonder nie dat naakte eiebelang en oppervlakkige soeke na genot (hedonisme) vandag so 'n belangrike rol speel. Sonder die regte norme word ontwikkeling en globalisering nie net leë begrippe nie, maar terselfdertyd uiters gevaarlik.

- In die lig van die voorafgaande is dit ook begryplik hoe die neokapitalistiese ekonomie - die dryfkrag agter ontwikkeling en globalisering (vgl. afdeling 5 van Van der Walt se artikel oor globalisering in hierdie nommer van In die Skriflig) - eeue-oue norme van die Christendom en ander wêreldreligieë en -kulture kan verdraai en vervang met presies die teenoorgestelde: egoïstiese eiebelang (dit het die vader van die kapitalisme, Adam Smith, al geleer) sou dan tot voordeel van almal wees.

Baie meer oorsake vir die talle mislukkings van ontwikkeling sou genoem kon word. Die heel belangrikste rede het in die voorafgaande al deurgeskemer, maar moet nou eksplisiet aan die orde kom. Dit is die feit dat ontwikkeling (en ook sy opvolger, globalisering) 'n sekulêre geloof is wat dus nie sy messiaanse droom van 'n ideale samelewing, 'n paradys van materiële oorvloed vir almal kon of ooit kan waarmaak nie.

\subsection{Ontwikkeling as 'n sekulêre religie}

Die grootste gevaar van die ontwikkelingsideaal is dat dit 'n religieuse kleur aangeneem het. As sodanig is dit nie verkeerd nie alles wat 'n mens dink of doen, is immers religieus bepaald. Die probleem is dat ontwikkeling 'n soort sekulêre religie geword het, terwyl voorstanders daarvan dit nie besef nie en selfs Christene dit nie raaksien nie en gevolglik maklik verlei kan word om dit onkrities te aanvaar. Die aandag word nou dus gevra vir enkele skrywers van Christelike oortuiging wat ons aandag hierop vestig. Omdat 'n mens so 'n insig nie van 'n sekulêre skrywer sou verwag nie, word so 'n skrywer se gedagtes in die verband daarna in meer besonderhede bespreek.

\subsubsection{Christelike denkers se visie op ontwikkeling}

Goudzwaard (1975:58) sê van die Westerse vooruitgangsidee, wat 'n sleutelelement in die hele ontwikkelingsideaal is: 
I have called this commitment to cultural progress a religion. For religion is man's search for salvation. We speak of Christianity as a religion. But alternatives in modern culture is just as much religious. They are alternative venues of salvation.

(Vgl. ook Goudzwaard, 1979 vir 'n grondige analise van die Westerse vooruitgangsideaal wat agter die idee van ontwikkeling lê.)

Zeylstra (1975:247) vestig die aandag daarop dat hierdie sekulêre religie van ontwikkeling en vooruitgang die resultaat was van die sekularisasie van oorspronklike Christelike toekomsverwagtings. Dit het veral gebeur tydens 'n nuwe periode van optimisme oor die moontlikheid van wetenskap, tegniek en ekonomie na die Tweede Wêreldoorlog.

The idea of man himself being capable of ensuring progress was a humanistic echo of the Medieval roots of the concept of development. It was the outcome of a quasi-religious exaltation of the faith in Western civilization once the horrors of World War II belonged to the past ... Western man came close to believing himself capable of replacing God in controlling ... human society.

'n Paar jaar later beklemtoon twee dosente aan die Vrije Universiteit van Amsterdam eweneens die religieuse karakter van ontwikkeling. Volgens Van Ufford en Schoffeleers is dit tipies van 'n religie om tussen twee wêrelde te onderskei: 'n hoëre, wat normatief is ten opsigte van 'n laere en ook ' $n$ verlossende rol ten opsigte van die laere wêreld moet vervul. In die ontwikkelingsreligie is die twee wêrelde die "ontwikkelde" en die "onderontwikkelde". Die onderontwikkelde wêreld moet deur aanvaarding van die "model" van die ontwikkelde wêreld sy eie probleme beter verstaan en oplos. Van die Westerse ontwikkelingsmodelle sê Van Ufford en Schoffeleers (1998:19) verder:

These models are salvific in that they contain not only a promise but also a prescription to make that promise come true. The development experts are the 'priests', who mediate between the two worlds. It is their task to keep alive the idea that to engage in development is a sacred duty. Hence the continuous emphasis on mobilization of the public opinion. Their authority cannot be doubted, because they are themselves the product of the reality which has become normative for the underdeveloped world ... our Western development models are tinged with this religious surplus value ... development may be viewed as a religious concept ... even if the 
relationship with the transcendent is formulated in essentially secular terms.

Wat bereik ons met die insig dat ontwikkeling na 'n sekulêre religie neig of dit reeds is? Die volgende kan genoem word

- Dit verklaar waarom vyftig jaar lank - ten spyte van mislukkings en kritiek - byna fanaties aan die (Westerse) ontwikkelingsideaal as die vanselfsprekende en enigste weg tot menslike welsyn vasgehou is.

- Dit ontbloot ontwikkeling as 'n sekulêre poging tot selfverlossing, wat as valse religie nooit sy beloftes van 'n aardse paradys kan vervul nie.

- Ontwikkeling word dan in plaas van bloot 'n tegnies-wetenskaplike (ekonomiese) metode, gesien as iets wat op mense en volke afgedwing word en nie bevraagteken mag word nie, maar waarin geglo moet word as iets wat vanselfsprekend goed is. Dit verklaar die doofheid en blindheid van die aanhangers van hierdie religie vir byvoorbeeld die roepstem van die armes of mense wat graag volgens eie kultuur, lewensvisie en religie wil "ontwikkel".

- Dit kan ons dus ook help om die soms skerp reaksie van die nieWesterse wêreld op Westerse ontwikkeling beter te verstaan. Hulle beskou dit tereg as 'n vreemde religie wat hulle eie diepste religieuse oortuigings aantas.

\subsubsection{Rist se visie op ontwikkeling as illusionêre religie}

Rist se konklusie stem ooreen met sommige van die voorafgaande denkers se afleidings, ook al behoort hy nie tot hulle tradisie nie. Volgens Rist (1999:21) is ontwikkeling die religie van die modernisme. Religie het dus nie met die aanbreek van die moderne tyd verdwyn nie, maar slegs na die (sogenaamde) sekulêre terrein geëmigreer. Rist (1999:218) praat ook van 'n "gesekulariseerde messianisme" en van die "messiaanse dekades" (Rist, 1999:216).

Die kern van hierdie ontwikkelingsgeloof - wat tans aan die wankel is - is volgens hom "an unchallenged belief in the necessity of growth". Hy beskryf dié geloof soos volg:

According to this belief the 'good life' can be assured for all through technological progress and everlasting production of goods and services - from which everyone will eventually benefit. Such 'development' then, offers the promise of general 
abundance, conceived in biological imagery as something 'natural', positive, necessary and indisputable (Rist, 1999:214).

Rist se boek toon aan hoe vir dekades lank byna fanaties aan hierdie geloof vasgehou is ten spyte daarvan dat uit die praktyk dikwels geblyk het dat dit nie kan werk nie. Dit is daarom wel aangepas maar - omdat dit ' $n$ religie is - nooit bevraagteken of afgewys nie.

Sy gevolgtrekking word in die volgende woorde saamgevat:

Development has never been more than a pretext for expanding the realm of the commodity, but throughout the 'messianic' period this was obscured by a stream of promises and policies, declarations and measures, which kept the illusion whereby people could be made to act in certain ways (Rist, 1999:227).

Ontwikkeling, dié religie van die Weste gedurende die tweede helfte van die twintigste eeu, was dus 'n illusie, 'n religieuse droom. Met hierdie bevinding van Rist het ons nie 'n probleem nie.

Dit wil egter voorkom asof Rist religie as sodanig as iets illusionêrs beskou. In 'n vroeëre artikel (Rist, 1990:5-8) oor "Development as the new religion of the West" vergelyk hy ontwikkeling met godsdienste soos die Christendom en kom tot die volgende resultate:

- Soos ander religieë is ontwikkeling iets onsigbaars en toekomstigs (dus 'n illusie?) waarop ons net kan hoop.

- Enigiets mag in die naam van ontwikkeling gedoen word, omdat dit as iets positief en onbetwisbaar beskou word. Om iets in die naam van "ontwikkeling" te doen, beteken feitlik dieselfde as om dit in die Naam van God te doen.

- Soos in die geval van 'n godsdiens, mag ontwikkeling self nie bevraagteken word nie. Daar mag alleen verskil word oor hoe dit verder bevorder kan word. Ontwikkeling self is egter 'n belangrike probleem, omdat dit sigself as die oplossing van alle probleme beskou.

- Ook die afwesigheid van enige keuse of alternatiewe is volgens Rist tipies van 'n religie. lemand wat ' $n$ ander weg sou voorstaan, sou volgens hom as a moderne ateïs deur hierdie sekulêre ontwikkelingsreligie geëkskommunikeer word.

By al sy goeie insigte moet ek van Rist verskil wanneer hy van mening is dat religie net slegte en geen goeie invloed kan hê nie, 
dat religieuse oortuigings as sodanig illusionêr en dus verwerplik is. (Vir 'n baie meer gebalanseerde standpunt oor sowel die positiewe as negatiewe invloed van godsdiens, vgl. Verbeek, 1991.) Hierdie standpunt het ook duidelike gevolge vir die eie oplossing wat hy vir die probleem aanbied. Rist (1999:224) erken aan die einde van sy boek dat ook die wetenskap - net soos religie - feilbaar is. Tog soek hy die oplossing (Rist, 1999:248 e.v.) in 'n nuwe (ekonomiese) wetenskaplike paradigma wat die uitgediende ontwikkelingsparadigma moet vervang. Hiermee sou saamgestem kon word, maar blykbaar moet dié nuwe wetenskap - in teenstelling met sy voorgangers - nie-messiaans, of nie-religieus van aard wees. Verval Rist nie hier in dieselfde illusie wat hy so duidelik ontbloot het nie, naamlik dat die (ontwikkelings)wetenskap nie religieus-neutraal kan wees nie?

Omdat die mens, ook in sy wetenskapsbeoefening en ontwikkelingswerk, 'n inherent religieuse wese is, kan die oplossing nie wees om enige religieuse beïnvloeding daarop te probeer uitban nie. Natuurlik kan godsdiens enigiets ook nadelig beïnvloed. Daarom is dit ons taak om te sorg dat religie nie 'n verblindende en verdowende rol speel nie, maar 'n gesonde invloed uitoefen.

Hoe kan dit gebeur? Dit bring ons by die slotgedeelte van hierdie artikel, naamlik of die gebreke van die gangbare, sekulêre ontwikkelingsideaal vanuit 'n Christelike perspektief getemper en selfs oorkom kan word.

\section{Ontwikkeling vanuit 'n Christelike perspektief}

In die lig van die monopolie van die huidige ontwikkelingsideale is, afgesien nog van die inhoud van moontlike alternatiewe, die blote feit dat daar ander moontlikhede bestaan al baie belangrik. Die aandag word dus hier gevestig op drie resente bydraes vanuit 'n Christelike perspektief.

\subsection{Miller se bydrae}

Miller (2001) gaan van die gedagte uit dat (religieuse en lewensbeskoulike) idees konkrete gevolge het - ook in die geval van ontwikkeling. Hy sê byvoorbeeld: "'For as he thinketh in his heart, so is he' (Proverbs 23:7 KJV). Development is more than working, even working hard. It is about thinking, and about what we think" (Miller, 2001:24). Elders:

All people and cultures have a particular model of the universe, or worldview. Their worldview does more to shape their 
development, their prosperity or poverty, than does their physical environment or their circumstances (Miller, 2001:34).

Hy ontleen heelwaarskynlik heelwat van sy gedagtes aan die belangrike werke van Weber (1958) en Harrison (1985 en 2000).

Miller illustreer hierdie uitgangspunt dwarsdeur sy boek met 'n vergelyking tussen drie verskillende lewensvisies: die animistiese lewensvisie (ook tipies van Afrika), die sekulêre, Westerse lewensvisie en die Bybelse lewensvisie. Hy doen dit na aanleiding van die volgende fasette van elke lewensvisie: hulle gods-, wets-, mens-, samelewings-, natuur- en tydsidees.

Dit bring Miller by die vraag wat ontwikkeling is en wat Christelike ontwikkelingswerk Christelik sal maak (Miller, 2001:49). Moet Christene hulle ontwikkelingswerk "verchristelik" deur bloot te sê dat hulle werk Christelik gemotiveerd is of raak dit ook die inhoud en doel van hulle ontwikkelingswerk?

Miller wil nie graag die woord "ontwikkeling" net so aanvaar nie, omdat die inhoud daarvan deur 'n sekulêre lewensvisie bepaal word. 'n Totaal nuwe woord sal egter nie maklik aanvaar word nie. Die Bybel ken ook nie, soos in die geval van baie ander moderne begrippe, die woord nie. Sy oplossing is om 'n ekwivalente Bybelse begrip, naamlik "rentmeesterskap" as uitgangspunt vir 'n meer holistiese, omvattende en ryker ontwikkelingsidee te gebruik.

Miller se omskrywing van ontwikkeling vanuit 'n Christelike perspektief kom grootliks ooreen met die drie skrywers wat hierna behandel word:

The goal of human development ... is that we become fully human. Man is to ... be 'perfect and complete', lacking nothing (see James 1:4; Colossians 1:28), mentally, physically, spiritually or relationally (Miller, 2001:277).

\subsection{Van Aalsburg se bydrae}

Ook Van Aalsburg wil nie die begrip "ontwikkeling" verwerp nie, maar wel die inhoud en rigting wat tans vanuit 'n sekulêre religie en lewensvisie daaraan gegee word. Hy vind die blote toevoeging van 'n paar Christelike waardes aan die bestaande begrip as onvoldoende. Veral as gevolg van bogenoemde twee eensydighede in die bestaande ontwikkelingspraktyk pleit hy vir 'n herformulering vanuit 'n Bybelse lewensvisie en norme. In dié verband werk hy met die belangrike Reformatoriese onderskeid tussen "struktuur" en 
"rigting". Eersgenoemde wys op God se goeie skepping (formasie), terwyl laasgenoemde dui op die afvallige religieuse koers na die sondeval (deformasie) asook die moontlikheid van herstel (reformasie) as gevolg van verlossing in Christus.

Van Aalsburg (2002:40-44) gebruik Van der Walt se breë omskrywing van ontwikkeling (Van der Walt, 1999:46) as vertrekpunt vir 'n alternatiewe Christelike perspektief. Die resultaat is 'n verdere verryking van Van der Walt se basisdefinisie en 'n "multivisionêre" in plaas van die gangbare eendimensionele, reduksionistiese visie op ontwikkeling.

Ten slotte lê Van Aalsburg ook die eerste eensydigheid van die gangbare ontwikkelingsideale bloot. Hy doen dit deur sy definisie toe te pas op die aktuele vraag van die verhouding tussen (Westerse) tegnologie en ontwikkeling en later nog meer spesifiek op landbouontwikkeling (vgl. Van Aalsburg, 2002:45-48). Sy hoofgedagte is dat die lokale (nie-Westerse) kulture nie geforseer mag word om by die Westerse tegnologie aan te pas nie, maar presies die omgekeerde: die Westerse tegnieke vir ontwikkeling moet by die lokale kultuur aanpas. Anders gestel: Westerse tegnologie moet nie ingevoer of oorgedra word nie, maar ontwikkeling moet begin en aansluit by die eie, kultureel bepaalde tegnologie van die nie-Westerse, ontwikkelende lande. Dan alleen kan tegnologie 'n dienende, vrugbare rol speel en bowendien ook veel goedkoper wees en makliker in stand gehou word.

\subsection{Vreugdenhil se bydrae}

Vreugdenhil (2003:9-33) gaan ter inleiding in op die geskiedenis van die ontwikkelingsideaal, die chroniese probleme wat dit vergesel, die moontlike redes daarvoor asook die kritiek op die motiewe en resultate, en die ontwikkelingsbegrip as sodanig. Ontwikkeling is volgens hom die resultaat van 'n bepaalde (sekulêre) werklikheidsvisie.

Ook hy verwerp nie ontwikkeling as sodanig nie (die strukturele), maar die eensydig ekonomies-tegniese aard daarvan. Die religieuse rigting (die normatiewe) moet verander, asook die eensydig Eurosentriese aard (vgl. weer die twee basiese eensydighede hierbo genoem). Vreugdenhil aanvaar Van der Walt se breë omskrywing van ontwikkeling as vertrekpunt en werk dit dan verder uit.

Vreugdenhil (2003:34-45) vergelyk die kulture en lewensvisies van die Westerse en nie-Westerse wêreld. Vervolgens lewer hy 'n 
belangrike, nuwe bydrae deur te besin oor hoe ontwikkeling vanuit 'n kultuureie perspektief behoort plaas te vind (vgl. Vreugdenhil, 2003:52-63). In dié verband vind hy waardevolle insigte by onder andere Haverkort, e.a. Ancient roots, new shoots (2002) waarvolgens ontwikkeling "geënt" behoort te word op die wortels van die bestaande, inheemse kulture. Die eie kultuur - en nie die Westerse nie - moet die beginpunt van ontwikkeling wees. (Dit is dus basies dieselfde gedagte as dié van Van Aalsburg, naamlik dat ontwikkeling by die bestaande, eie kultuur moet aansluit.) Die term hiervoor is endogene ontwikkeling. So 'n benadering los baie probleme van die ou Eurosentriese benadering op. (Vgl. in die verband weereens die waardevolle werk van Gyekye, 1997.)

Een (prinsipiële) probleem wat dit egter nie oplos nie ('n groot leemte in Haverkort, e.a.), is hoe so 'n endogene benadering met ' $n$ normatiewe (Christelik-Reformatoriese) versoen kan word. 'n Volstrekte endogene benadering waarin die eie kultuur die enigste maatstaf is, voldoen nie noodwendig aan Bybelse norme vir ontwikkeling nie - dit vereis 'n "supragene" benadering. Vreugdenhil is reg wanneer hy sê dat hoewel Westerse en nie-Westerse kulture wedersyds van mekaar moet leer, hulle albei uiteindelik volgens Bybelse (supragene) norme beoordeel moet word. Alleen sulke norme kan 'n nuwe rigting en dus ook 'n nuwe inhoud aan ontwikkeling gee.

\section{Eie perspektief}

Die drie reeds bespreekte voorbeelde van die bydrae wat 'n Christelike perspektief op ontwikkeling kan maak, was nie bedoel om ' $n$ volledige Christelike alternatief uit te spel nie. Hulle was slegs voorbeelde dat 'n Christelike bydrae wel moontlik en waardevol is. Ter afsluiting word vervolgens 'n eie perspektief gebied as deel van die gesprek oor ontwikkeling. As moontlike bydrae tot die besinning kan die volgende gestel word (vgl. ook Van der Walt [1999, 2001, 2003]):

In die eerste plek moet aangetoon word dat religieuse oortuigings en 'n lewensvisie die kern van enige kultuur vorm. 'n Lewensvisie behels 'n bepaalde gods-, wets-, mens-, samelewings-, tyd- en natuuridee. Vanuit hierdie perspektief wil ek die tradisionele Afrikakultuur en die moderne Westerse kultuur analiseer en kontrasteer. As dit gedoen word, blyk dat in hierdie twee kulture totaal verskillend oor die ideale samelewing gedink word en hulle nie anders kan nie as om te bots wanneer vroeër Westerse ontwikkelingsideale (en tans globalisering) op Afrika afgedwing word. 
Dit verklaar onder andere die talle mislukte ontwikkelingspogings in Afrika: dit gebeur ten diepste as gevolg van die onversoenbaarheid van twee heeltemal verskillende religieë, lewensvisies en kulture.

In die tweede plek kan ook 'n Christelike alternatief gebied word in die vorm van 'n nuwe omskrywing van wat holistiese ontwikkeling behoort te wees (vgl. Van der Walt, 1999:46-52; 2001:86-91):

Ontwikkeling is (1) die gebalanseerde ontsluiting van (2) al die vermoëns van die mens en (3) die moontlikhede van die res van die skepping (4) volgens God se doel daarmee en (5) sy wil daarvoor, sodat die mens in staat is om (6) in sy eie kultuur (7) sy roeping (8) as verantwoordelike rentmeester (9) in vryheid in die samelewing (10) tot eer van God te vervul (Van der Walt, 1999:46).

Met hierdie siening word dus twee eensydighede blootgelê:

- die eensydig Eurosentriese aard van ontwikkeling (die Westerse model moet as universele model vir ontwikkeling geld) en

- die eensydig ekonomies-tegniese aard van die gangbare, sekulêre ontwikkelingsideaal (die reduksionistiese aard daarvan).

Sowel Van Aalsburg (2002:40-44) as Vreugdenhil (2003:60) het Van der Walt se bostaande definisie van ontwikkeling oorgeneem in die uitwerk van hul eie Christelike alternatiewe.

Sulke pogings om 'n Christelike perspektief te stel sal - soos al ons Christelike werk - nie God se ryk laat aanbreek nie. Dit kan hoogstens tekens van sy komende koninkryk op die ontwikkelingsterrein oprig. Sulke tekens kan ons en ander, gedryf deur 'n verlange na die volmaakte ryk, inspireer om verder en dieper oor hierdie uiters aktuele vraagstuk te besin en die resultate daarvan ook konkreet te begin toepas. Hoewel ons Christelike denke en dade op hierdie terrein nie immuun is teen die verleidende mag van die sonde nie, hoef ons onsself nie vir die illusie van 'n sekulêre ontwikkelingsideaal te beywer nie.

Soos reeds gesuggereer, het hierdie illusie van die 20ste eeu - ten spyte van al die teenslae soos hier beskrywe - nog nie gesterf nie. Dit lewe in die 21ste eeu voort in 'n nuwe gedaante: globalisering. 


\section{Geraadpleegde bronne}

BUIJS, G.J., red. 2001. Als de olifanten vechten ... denken over ontwikkelingssamewerking vanuit Christelijk perspectief. Amsterdam: Buijten \& Schipperheijn.

DYERS, S. 2001. Selfstandige ontwikkeling van die Gereformeerde Kerke binne agtergeblewe gemeenskappe sedert 1994. In die Skriflig, 35(1):103-127, Maart.

ESCOBAR, A. 1995. Encountering development; the making and unmaking of the Third World. Princeton: Princeton University Press.

FOWLER, S. 1998. The development agenda; beyond dehumanising ideology. Orientation; International Circular of the Potchefstroom University for CHE, no. 87-90:401-443.

FOWLER, S. 2002. Transforming the development agenda. African Journal for Transformational Scholarship, 1(1):75-98, November.

GOUDZWAARD, B. 1975. Aid for the overdeveloped West. Toronto: Wedge Publishing Foundation.

GOUDZWAARD, B. 1979. Capitalism and progress; a diagnosis of Western society. Toronto: Wedge Publishing Foundation.

GOUDZWAARD, B. \& DE LANGE, H. 1994. Beyond poverty and affluence; towards an economy of care. Grand Rapids, Michigan: Eerdmans.

GYEKYE, K. 1997. Tradition and modernity; philosophical reflections on the African experience. Oxford: Oxford University Press.

HARRISON, D. 1988. The sociology of modernization and development. London/New York: Routledge.

HARRISON, L.E. 1985. Underdevelopment as a state of the mind; the Latin American case. Lanham: University Press of America.

HARRISON, L.E. 2000. Culture matters; how values shape human progress. New York: Basic Books.

HARRISON, P. 1987. The greening of Africa; breaking through the battle for land and food. London: Grafton Books.

HAVERKORT, B., 'T HOOFT, K., HIEMSTRA, W., eds. 2002. Ancient roots, new shoots; endogenous development in practice. London: Zed Books.

HETTNE, B. 1995. Development theory and the Three Worlds. Essex: Longman.

LEISTNER, E. 2003. African predicament; Africa wavering between past and modern time. Pretoria: Mlalo.

MILLER, D.L. 2001. Discipling nations; the power of truth to transform cultures. Seattle: Youth With a Mission Publishing.

NEEF, M. 1995. International development. Ongepubliseerde lesing gelewer op 31/10/1995 aan die Potchefstroomse Universiteit vir CHO.

RIST, G. 1990. Development as the new religion of the West. Quid pro quo, 1(2):5-8, April.

RIST, G. 1999. The history of development; from Western origins to global faith. Rondebosch: University of Cape Town Press.

RODNEY, W. 1989. How Europe underdeveloped Africa. Harare: Zimbabwe Pub. House.

SACHS, W. 1999. The archeology of the development idea. Interculture, 23(4):1-37.

SACHS, W., ed. 1992. The development dictionary. London: Zed Books. (Herdruk in 1993 in Johannesburg: Witwatersrand University Press.) 
SARDAR, Z. 1996. Beyond development; an Islamic perspective. The European Journal of Development Research, 8(2):36-55.

SCHNEIDER, B. 1988. The barefoot revolution; a report to the Club of Rome. London: Intermediate Technology.

SCHOEMAN, L.G. 2000. Die omgee-paradigma in die missionêre bediening met besondere verwysing na die werk van die N.G. Kerke in die Mnambithi-distrik (Ladysmith) van KwaZulu-Natal. Bloemfontein: Universiteit van die Oranje-Vrystaat. (D.Th.-proefskrif.)

SCHUURMAN, F.J., ed. 1993. Beyond the impasse; new directions in development theory. London \& New Jersey: Zed Books.

VAN AALSBURG, C. 2002. Ontwikkeling ontwikkeld; een reformatorisch wijsgerig reflectie op die relatie tussen wereldbeeld en visie op ontwikkeling. Wageningen: Wageningen Universiteit. (Ongepubliseerde skripsie.)

VAN DER WALT, B.J. 1999. Kultuur, lewensvisie en ontwikkeling; 'n ontmaskering van die gode van die onderontwikkelde Afrika en die oorontwikkelde Weste. Potchefstroom: Instituut vir Reformatoriese Studie.

VAN DER WALT, B.J. 2001. Culture, worldview and religion; towards a biblical perspective on development. (In Van der Walt, B.J. Transformed by the renewing of your mind. Potchefstroom: The Institute for Contemporary Christianity in Africa. p. 43-129.)

VAN DER WALT, B.J. 2003. Development of the African continent. (In Van der Walt, B.J. Understanding and rebuilding Africa. Potchefstroom: The Institute for Contemporary Christianity in Africa. p. 437-457.)

VAN DER WALT, B.J. 2004. Globalisering. Die nuwe gees van die 21ste eeu. In die Skriflig, 38(2):263-289.)

VAN UFFORD, P.O. \& SCHOFFELEERS, M., eds. 1988. Religion and development; towards an integrated approach. Amsterdam: Vrije Universiteit.

VERBEEK, G. 1991. The dialectics of socio-economic stratification and individual participation in rural development; an essay on the role of Christianity in the dynamics of socio-economic change. Den Haag: Institute of Social Studies. (M.A.-dissertation.)

VERHELST, 1990. No life without roots; culture and development. London: Zed Books.

VREUGDENHIL, J.J. 2003. Bouwen aan bruggen van hoop; over de culturele horizon in de multi-visionaire ontwikkelingspraktijk - een reformatorischwijsgerige reflectie. Wageningen: Wageningen Universiteit. (Ongepubliseerde skripsie.)

WEBER, M. 1958. The Protestant ethic and the spirit of Capitalism. New York: Scribner \& Sons.

WORLD BANK. 2000. World development report 2000/2001; attacking poverty. New York: Oxford Univ. Press.

ZEYLSTRA, W.G. 1975. Aid and development; the relevance of development aid to problems of developing countries. Leiden: Sijthoff.

\section{Kernbegrippe:}

kultuurverskille

modernisering

ontwikkeling: geskiedenis van; konsep van; Christelike benadering tot verwestering 


\section{Key concepts:}

cultural differences

development: concept of; history of; Christian perspective on Westernisation

modernisation 